\title{
Penentuan Metode Penilaian Persediaan dan Metode Penyusutan Aset Tetap untuk Tax Planning
}

\author{
Darti Djuharni $^{1^{*}}$, Yosefinne Yaksel Eunike Bezaliel ${ }^{2}$ \\ 1,2, STIE Malangkuçeçwara, Jl. Terusan Candi Kalasan, Malang, Indonesia
}

DOI: http://dx.doi.org/10.30587/jiatax.v2i2.1329

\begin{abstract}
Tax for companies is an expense that will reduce the company's net profit. To reduce the tax costs that must be paid, the company can make tax savings legally through the selection of inventory valuation methods and depreciation of fixed assets. The purpose of this study is to develop tax planning through the determination of inventory valuation methods and depreciation of fixed assets to minimize the tax burden on UD Master Jok. The method used is a descriptive analysis method that explains in detail related to tax planning through the method of valuing inventories and depreciation of fixed assets. The results showed that the selection of inventory valuation method with the average method and depreciation of fixed assets with the declining balance method can reduce the tax payable due to the increase in inventory costs and depreciation costs so that there are tax savings for the company.
\end{abstract}

Type of Paper: Empirical

Keywords: Firm Performance, Capital Structure, Trade-off Theory, Agency Theory, Growth

\section{Pengantar}

Pajak bagi negara merupakan sumber utama penerimaan karena digunakan untuk membiayai berbagai macam pengeluaran negara dan pembangunan nasional yang wajib dibayarkan oleh subjek pajak pribadi maupun badan (Pajak, 2019). Di sisi lain pajak bagi perusahaan merupakan beban yang akan mengurangi laba bersih perusahaan (Sugeng, 2011), sehingga beban pajak menjadi salah satu pusat perhatian bagi perusahaan. Sistem pajak yang ada di Indonesia saat ini memberikan wewenang kepada wajib pajak untuk menghitung serta melaporkan sendiri pajak terutangnya, sistem pajak ini dinamakan self assessment system (Syakura \& Baridwan, 2014). Melalui sistem ini pemerintah memberikan kepercayaan penuh kepada wajib pajak untuk melakukan manajemen pajaknya. Salah satu fungsi dalam manajemen pajak yaitu dengan melalui perencanaan pajak (tax planning). Perencanaan pajak dilakukan dengan tujuan agar jumlah yang dibayarkan perusahaan tidak melebihi dari jumlah yang seharusnya, dan semata-mata bukan untuk menghindari pembayaran pajak (Sugeng, 2011)

\footnotetext{
* Kontak penulis:

Email: dartidjuharni@yahoo.com

Afiliasi: STIE Malangkuçeçwara
} 


\section{Darti Djuharni, Yosefinne Yaksel Eunike Bezaliel}

Perencanaan pajak merupakan upaya pengelolaan usaha wajib pajak terkait dengan perpajakan guna meminimalkan pajak terutangnya selama tidak melanggar SAK ataupun undang-undang perpajakan yang berlaku (Sunyatama \& Ngumar, 2017). Adapun perencanaan pajak dapat dilakukan dengan beberapa cara, yaitu melalui pemilihan metode penilaian persediaan dan pemilihan metode penyusutan aset tetap. Kesalahan dalam pemilihan metode penilaian persediaan dapat mengakibatkan pada nilai persediaan akhir, harga pokok penjualan (HPP), laba kotor, dan pendapatan bersih pada laporan laba rugi (Setiyanto, 2012). Semakin tinggi nilai harga pokok penjualan, maka laba yang dihasilkan akan semakin rendah dan tentunya pajak yang harus dibayarkan menjadi lebih rendah. Oleh karena itu pemilihan metode penilaian persediaan yang tepat dapat meminimalkan besarnya laba perusahaan serta dapat berpengaruh pada jumlah pajak yang harus dibayarkan. Penggunaan metode penilaian persediaan yang dibolehkan menurut pajak untuk menghitung harga pokok penjualan adalah metode FIFO dan Average (Subekti, 2020). Perencanaan pajak selanjutnya yaitu melalui metode penyusutan aset tetap.

Besarnya biaya penyusutan tergantung pada metode yang digunakan. Menurut Ritonga (2017) metode penyusutan aset tetap yang digunakan perusahaan memiliki pengaruh terhadap nilai laba atau rugi perusahaan kedepannya sehingga dapat mempengaruhi besarnya pajak terutang yang harus dibayarkan. Penyusutan aktiva tetap dapat dilakukan dengan berbagai metode antara lain metode garis lurus, saldo menurun, jam jasa, jumlah unit produksi, berdasarkan jenis dan kelompok dan anuitas

Berdasarkan peraturan perpajakan terdapat pada UU Pajak Penghasilan Pasal 11 metode yang diperbolehkan untuk aset tetap berwujud bukan bangunan adalah metode garis lurus dan metode saldo menurun, serta untuk bangunan metode yang digunakan adalah garis lurus (Mattalatta, 2008). Dalam melakukan perencanaan pajak, perusahaan akan membuat seefektif mungkin agar mereka tidak sekedar memperoleh keuntungan dari segi pajak, tetapi juga akan memperoleh tambahan modal dari pihak investor (Aditama \& Purwaningsih, 2014). Hasil penelitian lain yang berkaitan dengan perencanaan pajak dikemukakan oleh beberapa pihak sebagaimana diuraikan berikut ini.

Syakura and Baridwan (2014) menyebutkan bahwa beban pajak dapat dikurangi dengan melakukan perencanaan pajak yang baik, sehingga kelebihan dana dapat digunakan untuk kegiatan operasional berikutnya. Ritonga (2017) menggunakan variable penyusutan aset tetap dan revaluasi aset tetap memaparkan bahwa perencanaan pajak dengan melakukan revaluasi dan saldo menurun dapat mengurangi perhitungan pajak terutangnya. Penelitian lainnya dilakukan Katuuk (2013) menggunakan variabel revaluasi aktiva tetap menyatakan bahwa revaluasi akan menghasilkan kenaikan nilai pasar wajar yang diakui sebagai biaya amortisasi aktiva dan nantinya akan mempengaruhi turunnya nilai laba usaha serta berdampak pada pengurangan beban pph badan. Penelitian berikut dilakukan oleh Tan, Sumarsan, and Siahaan (2017) menggunakan variabel metode penyusutan dan revaluasi aktiva tetap sebagai bentuk perencanaan pajak menyatakan bahwa dengan penggunaan metode penyusutan aset tetap saldo menurun dan penerapan revaluasi aktiva tetap dapat menambah biaya dan berdampak pada penghematan pajak badan sebesar 25\%. Penelitian lainnya dilakukan oleh Alamsyah (2019) dengan menggunakan variabel metode penyusutan dan revaluasi aset tetap memaparkan bahwa penerapan metode penyusutan aset tetap dengan garis lurus dan revaluasi aktiva tetap akan berdampak pada rendahnya pajak penghasilan badan. Penelitian berikut dilakukan oleh Ratag (2013) dengan menggunakan variabel metode penyusutan aset tetap menyatakan bahwa penerapan metode penyusutan dengan garis lurus menghasilkan biaya penyusutan yang lebih besar yang berdampak pada turunnya beban pajak terutang di PT Bank Sulut.

Berdasarkan beberapa penelitian sebelumnya, tampak bahwa kebanyakan peneliti hanya mengkaji berdasarkan metode penyusutan aset tetap dan revaluasi aset tetap. Sejauh ini belum ditemukan penelitian yang terkait dengan pemilihan metode penilaian persedian. Oleh karena itu mengacu kepada lima penelitian terdahulu, peneliti akan mengkaji metode penyusutan aset tetap dan menambahkan satu variabel dalam melakukan strategi perencanaan pajak yaitu variabel pemilihan metode persediaan. Dengan demikian penelitian ini ditujukan untuk 141

JIATAX 2 (2) 140-148 (2019) 


\section{Darti Djuharni, Yosefinne Yaksel Eunike Bezaliel}

menyusun perencanaan pajak melalui penentuan metode persediaan dan aset tetap guna meminimalkan beban pajak.

\section{Literature Review}

\subsection{Perencanaan Pajak}

Perencanaan pajak merupakan langkah awal dalam manajemen pajak. Kegiatan perencanaan pajak dilakukan bukan untuk menghindari pajak, melainkan mengefisienkan jumlah yang harus dibayarkan oleh wajib pajak (Syakura \& Baridwan, 2014). Penekanan terhadap perencanaan pajak (tax planning) adalah meminimalkan kewajiban pajak, tetapi tetap dalam koridor peraturan perpajakan. Upaya yang dilakukan untuk meminimalkan besarnya pajak yang harus dibayarkan dapat dilakukan dengan beberapa cara (Suandi, 2017), yaitu: memilih bentuk badan hukum, memilih lokasi perusahaan, memaksimalkan biaya-biaya, mendirikan perusahaan dalam satu jalur usaha, mendirikan perusahaan ada yang sebagai pusat laba dan pusat biaya, memberikan tunjangan tidak dalam bentuk natura/kenikmatan, pemilihan metode persediaan, pemilihan metode penyusutan. Penerapan perencanaan pajak memiliki beberapa manfaat yang dinyatakan oleh (Mardiasmo, 2011) bahwa dengan perencanaan pajak timbul penghematan kas keluar, artinya bahwa perencanaan pajak dapat mengurangi beban pajak yang merupakan biaya bagi perusahaan, selain itu perencanaan pajak dapat mengatur aliran kas (cash flow), artinya perencanaan pajak dapat mengestimasikan kebutuhan kas untuk pajak dan menentukan pembayaran sehingga dapat menyusun kas secara akurat.

Berdasarkan hasil penelitian Ratag (2013) tentang Perencanaan Pajak Melalui Metode Penyusutan Aktiva Tetap menunjukkan hasil adanya selisih Laba Kena Pajak yang dihemat setelah dilakukan penghitungan dengan menggunakan tax planning untuk periode yang berakhir pada tahun 2012. Begitu juga yang dilakukan oleh Alamsyah (2019) Hasil penelitian menyimpulkan bahwa Perencanaan pajak yang dilaksanakan oleh PT. PP (Persero), Tbk dengan menggunakan saldo menurun menunjukkan nilai pajak yang dibayarkan lebih kecil dibandingan dengan menggunakan metode penyusutan garis lurus.

\subsection{Penilaian Persediaan}

Penentuan metode penilaian persediaan cukup penting dalam perencanaan pajak terutama untuk perusahaan yang bergerak di bidang manufaktur dan perdagangan. Untuk efisiensi pajak, pemilihan metode persediaan adalah langkah baik karena kesalahan dalam pemilihan metode persediaan dapat berakibat pada nilai persediaan akhir, harga pokok penjualan (CGS), laba kotor dan pendapatan bersih pada laporan laba rugi (Setiyanto, 2012). Semakin tinggi nilai harga pokok penjualan, maka laba yang didapatkan akan rendah dan berdampak juga pada rendahnya pajak yang dibayarkan.

Penetapan besarnya nilai persediaan harus sesuai UU Pajak Penghasilan Nomor 36 Tahun 2008 Pasal 10 ayat 6 (Mattalata, 2008) yaitu menggunakan metode average atau FIFO. Dalam metode rata-rata biaya barang tersedia untuk dijual (persediaan awal dan pembelian) dibagi dengan kuantitas unit yang tersedia untuk dijual, untuk mendapatkan biaya rata-rata per unit. Apabila perusahaan menggunakan metode pencatatan periodik, maka biaya rata-rata per unit hanya dihitung sekali di akhir periode saja. Di sisi lain dalam pencatatan perpetual dilakukan pada setiap kali pembelian dan dihitung biaya rata-rata per unit baru.

Pada metode harga pokok persediaan akan dibebankan sesuai dengan urutan terjadinya. Harga pokok untuk penjualan dan pemakaian barang dilakukan dengan membebankan lebih dulu barang yang paling dulu masuk atau keluar, disusul yang masuk berikutnya, sedangkan persediaan akhir dibebani harga pokok terakhir. Penyusutan aset tetap telah diakui oleh fiskus sejak tahun 1995 yang terdiri dari 2 metode yaitu metode garis lurus dan saldo menurun. 


\section{Darti Djuharni, Yosefinne Yaksel Eunike Bezaliel}

Adapun dalam UU PPh No 36 Tahun 2008 menyatakan bahwa semua aset tetap berwujud harus dikelompokan dahulu sesuai golongan sebagai berikut: aset tetap kelompok bukan bangunan dan aset tetap kelompok bangunan. Kelompok masa manfaat dan tarif penyusutan ditunjukkan pada tabel berikut ini.

Tabel 1. Kelompok Harta Berwujud.

\begin{tabular}{lccc}
\hline Kelompok & Masa Manfaat & Garis Lurus $(t)$ & Saldo Menurun $(t)$ \\
\hline 1.Bukan Bangunan & & & \\
\hline Kelompok I & 4 Tahun & $25 \%$ & $50 \%$ \\
\hline Kelompok II & 8 Tahun & $12,5 \%$ & $25 \%$ \\
\hline Kelompok III & 16 Tahun & $6,25 \%$ & $12,5 \%$ \\
\hline Kelompok IV & 20 Tahun & $5 \%$ & $10 \%$ \\
\hline 2. Bangunan & & & \\
\hline Permanen & 20 Tahun & $5 \%$ & \\
\hline Tidak Permanen & 10 Tahun & $10 \%$ & \\
\hline
\end{tabular}

Nilai penyusutan tiap-tiap metode akan menghasilkan nilai yang berbeda. Menurut Suandi (2017) penyusutan dengan metode garis lurus akan menghasilkan beban penyusutan yang besarnya sama tiap periode, sedangkan penyusutan dengan metode saldo menurun akan menghasilkan beban penyusutan yang lebih besar pada awal periode dan semakin menurun pada periode-periode selanjutnya. Ritonga (2017) menyatakan bahwa metode penyusutan aset tetap yang digunakan perusahaan memiliki pengaruh terhadap nilai laba atau rugi perusahaan kedepannya sehingga dapat mempengaruhi besarnya pajak yang terutang.

\section{Metodologi Penelitian}

Penelitian ini menggunakan pendekatan deskriptif analisis, yang tujuannya untuk menjelaskan atau mendeskripsikan suatu peristiwa atau kejadian (Setyosari, 2010). Pada kajian ini dijabarkan secara rinci kondisi perusahaan terkait dengan perencanaan pajak. Data diperoleh langsung dari UD Master Jok berupa laporan laba rugi, catatan persediaan, dan daftar aset tetap. Data dikumpulkan melalui observasi dan dokumentasi, serta tanya jawab kepada pimpinan untuk hal-hal yang perlu penjelasan lebih lanjut.

Langkah-langkah yang dilakukan untuk menganalisis data meliputi (1) mendeskripsikan kondisi laporan keuangan perusahaan berupa Laporan L/R tahun 2018, catatan persediaan meliputi data pembelian dan penjualan tahun 2018, serta daftar aset tetap berupa harga dan tahun perolehan; (2) melakukan analisis terhadap laporan keuangan; (3) melakukan perencanaan pajak dengan menghitung nilai persediaan dan harga pokok dengan metode FIFO dan average; serta membandingkan besarnya nilai persediaan diantara dua metode guna melakukan penghematan pajak. Selanjutnya, (4) melakukan perencanaan pajak melalui metode penyusutan aktiva tetap, dengan cara: (1) pengelompokan aset tetap berdasarkan kelompok sesuai peraturan perpajakan; (2) melakukan perhitungan beban penyusutan aset tetap bangunan dengan metode garis lurus; (3) membandingkan hasil penyusutan bangunan menurut perusahaan dan perpajakan; (4) melakukan perhitungan beban penyusutan aset tetap bukan bangunan dengan metode garis lurus dan saldo menurun; (5) membandingkan hasil penyusutan bukan bangunan menurut perusahaan dan perpajakan; (6) menentukan metode penyusutan yang tepat untuk perencanaan pajak; (7) membandingkan 


\section{Darti Djuharni, Yosefinne Yaksel Eunike Bezaliel}

laporan L/R fiskal sebelum dan sesudah dilakukannya perencanaan pajak; serta terakhir menghitung besarnya penghematan pajak

\section{Hasil dan Pembahasan}

\subsection{Analisis Deskriptif}

UD Master Jok merupakan usaha dagang yang bergerak di bidang produksi jok mobil dan menyediakan juga jasa cat mobil serta pemeliharaan dan perbaikan mobil. Usaha ini berada di Kota Pare - Kediri dan memiliki 29 karyawan di bagian produksi. Secara umum perusahaan ini merupakan wajib pajak yang patuh, karena selalu membayarkan kewajiban pajaknya kepada pemerintah, tetapi selama ini perusahaan belum melakukan perencanaan pajak yang sistematis karena ketidakpahamannya terhadap hal ini. Data yang digunakan sebagai dasar penyusunan perencanaan pajak adalah laporan keuangan tahun 2019. Berdasarkan laporan laba rugi tahun 2019, perusahaan memperoleh laba setelah pajak yang cukup besar yaitu $\mathrm{Rp}$ 1.465.071.398. Hasil analisis terhadap laporan Laba rugi menunjukkan hasil : rasio gross profit margin sebesar $40,18 \%$, net profit margin $=29,4 \%$, dan rasio untuk biaya operasional terhadap penjualan sebesar $6,65 \%$. Kondisi ini menunjukkan perusahaan sangat effisien dalam penggunaan biaya operasional.

Data berikutnya yang diperoleh adalah pembelian bahan baku dan penjualan. Pembelian bahan baku berupa kain mb tech, kain invity, spons, furing, benang, lem, dan kawat selama tahun 2019 menghabiskan dana sebesar Rp 2.782,965,000, sedangkan penjualan jok mobil selama tahun 2019 sebesar $\mathrm{Rp}$ 4.983.000.000. Data ini akan digunakan untuk perhitungan penilaian persediaan guna melakukan perencanaan pajak.

\subsection{Perencanaan Pajak}

Perencanaan pajak dilakukan melalui metode penilaian persediaan dengan cara menghitung nilai persediaan akhir berdasarkan metode FIFO dan Average. Hasil perhitungan dengan dua metode tersebut ditunjukkan pada tabel berikut ini.

Tabel 2 Penghitungan Penilaian Persediaan Bahan Baku

\begin{tabular}{|c|c|c|c|}
\hline Bahan Baku & FIFO & Average & Selisih \\
\hline MB Tech & Rp 120.960.000 & Rp 120.842 .856 & Rp 117.144 \\
\hline Invinty & $\mathrm{Rp} \quad 81.900 .000$ & $\mathrm{Rp} \quad 81.757 .105$ & Rp 142.895 \\
\hline Spons & $\mathrm{Rp} \quad 47.700 .000$ & $\mathrm{Rp} \quad 47.398 .416$ & $\mathrm{Rp} 301.584$ \\
\hline Furing & 300,000 & 295.172 & $\begin{array}{ll}\mathrm{Rp} & 4.828\end{array}$ \\
\hline Benang & $\mathrm{Rp} \quad 1.450 .000$ & $\mathrm{Rp} \quad 1.486 .779$ & $\mathrm{Rp} \quad 36.779$ \\
\hline Lem & $\mathrm{Rp} \quad 3.200 .000$ & $\mathrm{Rp} \quad 3.177 .041$ & Rp $\quad 22.959$ \\
\hline Kawat & 80.000 & 80.000 & - \\
\hline Total & Rp 255.590.000 & Rp 255.037.369 & Rp 522.631 \\
\hline
\end{tabular}

Dari perhitungan nilai persediaan akhir bahan baku tahun 2019 terdapat perbedaan jumlah harga keseluruhan antara metode FIFO dan Average. Dapat diketahui bahwa perhitungan penilaian persediaan dengan menggunakan metode FIFO menghasilkan nlai persediaan akhir yang lebih besar dengan selisih perhitungan nilai persediaan akhir dengan 144

JIATAX 2 (2) 140-148 (2019) 


\section{Darti Djuharni, Yosefinne Yaksel Eunike Bezaliel}

kedua metode yaitu sebesar Rp 522.631. Hasil perhitungan harga pokok penjualan ditunjukkan berikut ini:

$$
\begin{aligned}
& \text { Berdasarkan metode FIFO = Rp 2.980.726.850,00 } \\
& \text { Metode Average } \\
& \begin{array}{ll}
\text { Rp } 2.981 .279 .481,00 \\
\text { Selisih } & \text { Rp } 552.361,00
\end{array}
\end{aligned}
$$

Pada perhitungan harga pokok penjualan, nilai persediaan akhir memiliki pengaruh yang cukup penting karena semakin kecil nilai persediaan akhir bahan baku maupun barang jadi, maka akan semakin besar nilai harga pokok penjualan yang dihasilkan. Besarnya nilai

\begin{tabular}{|c|c|c|c|c|c|c|c|c|c|}
\hline \multirow{2}{*}{ No } & \multirow{2}{*}{ Keterangan } & \multirow{2}{*}{ Tahun } & \multicolumn{5}{|c|}{ Perolehan } & \multirow{2}{*}{ Kel } & \multirow{2}{*}{ UE } \\
\hline & & & Unit & & Harga & & Jumlah & & \\
\hline & Bangunan & & & & & & & & \\
\hline 1 & Kantor & 2001 & 1 & $\mathrm{Rp}$ & $400,000,000$ & $\mathrm{Rp}$ & $400,000,000$ & $\mathrm{P}$ & 20 \\
\hline 2 & Pabrik Pare & 2001 & 2 & $\mathrm{Rp}$ & $1,100,000,000$ & $\mathrm{Rp}$ & $2,200,000,000$ & $\mathrm{P}$ & 20 \\
\hline 3 & Pabrik Kediri & 2007 & 1 & $\mathrm{Rp}$ & $1,500,000,000$ & $\mathrm{Rp}$ & $1,500,000,000$ & $\mathrm{P}$ & 20 \\
\hline
\end{tabular}
harga pokok penjualan akan menjadikan beban pajak yang ditanggung menjadi lebih kecil.

\section{Tabel 4 Pengelompokan Aset Tetap Bangunan}

\begin{tabular}{|c|c|c|c|c|c|c|c|c|c|}
\hline \multirow{2}{*}{ No } & \multirow{2}{*}{ Keterangan } & \multirow{2}{*}{ Tahun } & \multicolumn{5}{|c|}{ Perolehan } & \multirow{2}{*}{ Kel } & \multirow{2}{*}{ UE } \\
\hline & & & Unit & Har & & Jum & lah & & \\
\hline \multirow[t]{2}{*}{1} & Mesin Jahit & 2007 & 20 & $\mathrm{Rp}$ & $8,000,000$ & $\mathrm{Rp}$ & $160,000,000$ & 3 & 16 \\
\hline & Kendaraan & & & & & & & & \\
\hline 1 & Pick Up Mitsubishi & 2013 & 1 & $\mathrm{Rp}$ & $50,000,000$ & $\mathrm{Rp}$ & $50,000,000$ & 2 & 8 \\
\hline \multirow[t]{2}{*}{2} & Motor & 2014 & 7 & $\mathrm{Rp}$ & $10,000,000$ & $\mathrm{Rp}$ & $70,000,000$ & 2 & 8 \\
\hline & Inventaris & & & & & & & & \\
\hline 1 & Komputer & 2014 & 1 & $\mathrm{Rp}$ & $8,650,000$ & $\mathrm{Rp}$ & $8,650,000$ & 2 & 8 \\
\hline 2 & Kursi Direktur & 2017 & 1 & $\mathrm{Rp}$ & $1,265,000$ & $\mathrm{Rp}$ & $1,265,000$ & 1 & 4 \\
\hline 3 & Kursi Staf & 2017 & 1 & $\mathrm{Rp}$ & 675,000 & $\mathrm{Rp}$ & 675,000 & 1 & 4 \\
\hline 4 & 1 Set Kursi Tamu & 2017 & 1 & $\mathrm{Rp}$ & $2,700,000$ & $\mathrm{Rp}$ & $2,700,000$ & 1 & 4 \\
\hline 5 & Meja Direktur & 2016 & 1 & $\mathrm{Rp}$ & 498,000 & $\mathrm{Rp}$ & 498,000 & 1 & 4 \\
\hline 6 & $\mathrm{AC}$ & 2013 & 1 & $\mathrm{Rp}$ & $1,345,000$ & $\mathrm{Rp}$ & $1,345,000$ & 2 & 8 \\
\hline 7 & Meja Staf & 2016 & 1 & $\mathrm{Rp}$ & 498,000 & $\mathrm{Rp}$ & 498,000 & 1 & 4 \\
\hline 8 & Kursi Pegawai & 2017 & 25 & $\mathrm{Rp}$ & $3,000,000$ & $\mathrm{Rp}$ & $75,000,000$ & 1 & 4 \\
\hline 9 & Printer & 2017 & 1 & $\mathrm{Rp}$ & 765,000 & $\mathrm{Rp}$ & 765,000 & 2 & 8 \\
\hline 11 & Telepon & 2018 & 1 & $\mathrm{Rp}$ & 345,000 & $\mathrm{Rp}$ & 345,000 & 1 & 4 \\
\hline
\end{tabular}

Tabel 5 Pengelompokan Aset Tetap Bukan Bangunan 


\section{Darti Djuharni, Yosefinne Yaksel Eunike Bezaliel}

Berdasarkan uraian di atas, dapat disimpulkan bahwa penilaian persediaan dengan menggunakan metode Average menghasilkan harga pokok penjualan yang lebih besar dibandingkan dengan metode FIFO. Oleh karena itu, perencanaan pajak pada UD Master Jok dapat dilakukan dengan diterapkannya penilaian persediaan dengan menggunakan metode Average.

Perencanaan Pajak melalui metode penyusutan aset tetap tampak pada langkah-langkah berikut. (1) Mengelompokkan aset tetap, sebagaimana tampak pada tabel 4 dan 5 . Hasil perhitungan beban penyusutan aset tetap berupa bangunan antara perhitungan perusahaan dan melalui perencanaan pajak, tampak pada tabel 6.

Tabel 6 Rekapitulasi Perbandingan Penyusutan Aset Tetap Bangunan

\begin{tabular}{|c|c|c|c|c|}
\hline Bangunan & & Perusahaan & & Perpajakan \\
\hline Kantor & $\mathrm{Rp}$ & $16,000,000$ & $\mathrm{Rp}$ & $20,000,000$ \\
\hline Pabrik Pare & $\mathrm{Rp}$ & $88,000,000$ & $\mathrm{Rp}$ & $110,000,000$ \\
\hline Pabrik Kediri & $\mathrm{Rp}$ & $60,000,000$ & $\mathrm{Rp}$ & $75,000,000$ \\
\hline Total & $\mathrm{Rp}$ & $164,000,000$ & $\mathrm{Rp}$ & $205,000,000$ \\
\hline
\end{tabular}

Berdasarkan hasil perhitungan pada tabel di atas, penyusutan untuk aset tetap bangunan baik secara komersial maupun fiskal menggunakan metode garis lurus dan diperoleh total penyusutan tahun 2019 sebesar Rp 205.000.000. Pada laporan laba rugi tahun 2019, UD Master Jok mencatat beban penyusutan untuk bangunan sebesar Rp 164.000.000. Beban penyusutan fiskal diperoleh hasil yang lebih tinggi daripada biaya penyusutan komersial dengan selisih $\mathrm{Rp}$ 41.000.000. Hal ini dikarenakan perbedaan penentuan masa manfaat antara perusahaan dengan peraturan perpajakan . Masa manfaat bangunan yang ditetapkan UD Master Jok adalah 25 tahun sedangkan menurut perpajakan yang diperbolehkan masa manfaat bangunan adalah 20 tahun.

Perbandingan hasil perhitungan penyusutan aset tetap secara garis lurus menunjukkan hasil sebagai berikut:

- Menurut perhitungan perusahaan secara garis lurus sebesar Rp 34.134.292,00.

- Menurut perpajakan secara garis lurus sebesar $=\operatorname{Rp} 46.341 .250,00$, perhitungan dengan saldo menurun sebesar Rp 71.885.578,00

Dalam perencanaan pajak melalui metode penyusutan, pemilihan metode yang menghasilkan biaya lebih besar akan sangat menguntungkan bagi perusahaan. Hal ini dikarenakan semakin besar biaya yang dikeluarkan, maka laba yang dihasilkan akan semakin rendah dan berdampak pada rendahnya juga pajak yang terutang. Berdasarkan uraian di atas, pemilihan metode saldo menurun lebih tepat untuk perencanaan pajak (tax planning).

Setelah melakukan rekonsiliasi fiskal dan perencanaan pajak, dihasilkan rincian laporan laba rugi setelah perencanaan pajak dan rekonsiliasi fiskal seperti tergambar pada tabel 8 . Berdasarkan hasil perhitungan di atas dapat diketahui untuk nilai HPP sebelum perencanaan pajak dan setelah perencanaan pajak terdapat selisih Rp 552,631( Rp 2.981.279.481 - Rp 2.980.726.859). Sebelum perencanaan pajak perusahaan menggunakan metode FIFO dan setelah perencanaan pajak menggunakan metode Average, karena dengan penerapan metode Average, nilai persediaan akhir menjadi lebih kecil dibanding dengan metode FIFO dan menyebabkan nilai HPP menjadi lebih besar. Biaya penyusutan sebelum dilakukan perencanaan pajak dibebankan sebesar Rp 198.134.292, setelah dilakukan perencanaan pajak, biaya penyusutan naik menjadi $\mathrm{Rp} 276.885 .578$; selisih biaya penyusutan sebelum dan setelah dilakukan perencanaan pajak adalah $R p$ 78.751.286 $(R p$ 276.885.578 - Rp 198.134.292). 
Tabel 8 - Laporan Laba Rugi Fiskal Sebelum dan Sesudah Perencanaan Pajak Untuk Tahun Yang Berakhir 31 Desember 2019

(dalam Rp)

\begin{tabular}{|c|c|c|c|}
\hline Keterangan & $\begin{array}{c}\text { Sebelum } \\
\text { Perencanaan } \\
\text { Pajak }\end{array}$ & $\begin{array}{c}\text { Setelah } \\
\text { Perencanaan Pajak }\end{array}$ & Selisih \\
\hline Penjualan & $4,983,000,000$ & $4,983,000,000$ & \\
\hline Harga Pokok Penjualan & $2,980,726,859$ & $2,981,279,481$ & 552,631 \\
\hline Laba Kotor & $2,002,273,150$ & $2,001,720,519$ & \\
\hline \multicolumn{4}{|l|}{ Biaya Usaha : } \\
\hline Biaya Gaji & $90,000,000$ & $90,000,000$ & \\
\hline Biaya LTA & $15,000,000$ & $15,000,000$ & \\
\hline Biaya ATK & 917,500 & 917,500 & \\
\hline Biaya Asuransi & $12,300,000$ & $12,300,000$ & \\
\hline Biaya Penyusutan & $198,134,292$ & $276,885,578$ & $78,751,286$ \\
\hline Biaya Reparasi & $5,775,000$ & $5,775,000$ & \\
\hline Biaya Lain-lain & $6,576,700$ & $6,576,700$ & \\
\hline Total Biaya & $328,702,792$ & $407,454,778$ & \\
\hline Laba Bersih Sebelum Pajak & $1,673,570,358$ & $1,594,265,741$ & $76,159,831$ \\
\hline Pajak & $216,879,000$ & $206,601,867$ & $10,277,133$ \\
\hline Laba Bersih Setelah Pajak & $1,465,071,398$ & $1,387,663,874$ & \\
\hline
\end{tabular}

Dari hasil analisis diketahui bahwa terdapat perbedaan besarnya pajak yang harus ditanggung perusahaan sebelum dan sesudah dilakukan perencanaan pajak. Sebelum perencanaan pajak, beban pajak yang harus ditanggung perusahaan adalah sebesar $\mathrm{Rp}$ 216.878.909, sedangkan jika perusahaan melakukan perencanaan pajak maka beban pajak yang ditanggung perusahaan sebesar Rp 206.601.867 sehingga terdapat selisih penghematan pajak sebesar Rp 10.277.133 ( Rp 216.879.000 - Rp 206.601.867 ).

Dari perhitungan ini tampak ada penghematan pajak sebesar Rp 9.868.625. Jumlah ini tergolong nilai yang cukup besar dan menguntungkan perusahaan serta dapat dialokasikan untuk kepentingan perusahaan lainnya. Penggunaan metode average dalam menilai persediaan dapat diterapkan dan memberikan pengaruh yang menguntungkan perusahaan dengan batasanbatasan kondisi, seperti keadaan ekonomi yang mengalami fluktuasi dimana harga bahan baku di pasaran mengalami kenaikan dan penurunan yang cukup signifikan. Dalam hal ini penilaian persediaan menggunakan metode average akan lebih baik daripada metode FIFO, serta pemilihan metode penyusutan aset tetap dengan menerapkan metode saldo menurun akan menghasilkan biaya yang lebih besar dibandingkan metode saldo menurun sehingga dari pemilihan metode-metode tersebut dapat menjadikan pajak terutang perusahaan menjadi lebih kecil. 


\section{Darti Djuharni, Yosefinne Yaksel Eunike Bezaliel}

\section{Kesimpulan}

Berdasarkan tujuan yang telah ditetapkan dalam penelitian ini dapat disimpulkan bahwa penyusunan perencanaan pajak dengan menilai persediaan menggunakan metode yang tepat akan menghasilkan penghematan pajak. Begitu juga pemilihan metode penyusutan aktiva tetap yang sesuai akan dapat menghemat pajak. Hasil perhitungan dan perencanaan pajak yang sesuai untuk UD Master Jok adalah menggunakan metode penilaian persediaan Average dan metode penyusutan aset tetap saldo menurun yang hasilnya dapat menghemat pajak sebesar Rp 10.277.133,00.

\section{Daftar Pustaka}

Aditama, F., \& Purwaningsih, A. (2014). Pengaruh Perencanaan Pajak Terhadap Manajemen Laba Pada Perusahaan Non Manufaktur Yang Terdaftar Di Bursa Efek Indonesia. MODUS Vol.26(1), 33-50.

Alamsyah, A. R. (2019). Penerapan Perencanaan Pajak melalui Metode Penyusutan dan Revaluasi Aset Tetap. Jurnal Riset dan Aplikasi: Akuntansi dan Manajemen, 3(3), 189204.

Indonesia, I. A. (2015). Pernyataan Standar Akuntansi Keuangan Jakarta: Dewan Standar Akuntansi Keuangan.

Katuuk, Y. C. (2013). Analisis Perencanaan Pajak Melalui Revaluasi Aktiva Tetap pada PT Angkasa Pura (PERSERO) Bandara Sam Ratulangi. Jurnal EMBA, 1(3), 540-550.

Mardiasmo. (2011). Perpajakan Edisi Revisi 2011. Yogyakarta.

Undang-Undang RI Nomor 36 Tahun 2008 Tentang Pajak Penghasilan (2008).

UNDANG-UNDANG REPUBLIK INDONESIA: Perubahan Keempat Atas Undang-Undang Nomor 7 Tahun 1983 Tentang Pajak Penghasilan, Nomor 36 Tahun 2008 C.F.R. (2008).

Pajak, D. J. (2019). Fungsi Pajak, from https://www.pajak.go.id/id/fungsi-pajak

Ratag, G. A. (2013). Perencanaan Pajak Melalui Metode Penyusutan Aktiva Tetap Untuk Menghitung PPh Badan Pada PT Bank Sulut. Jurnal EMBA, 1(3), 950-958.

Ritonga, P. (2017). Analisis Perencanaan Pajak Melalui Metode Penyusutan dan Revaluasi Aset Tetap untuk Meminimalkan Beban Pajak pada PT Taspen (Persero). Jurnal Riset Akuntansi dan Bisnis, 17(1), 1-14.

Setiyanto, K. B. (2012). Analisis Faktor-Faktor yang Berpengaruh terhadap Pemilihan Metode Akuntansi Persediaan. Journal of Accounting Research Universitas Diponegoro.

Setyosari, P. (2010). Metode Penelitian Pendidikan dan Pengembangan Jakarta: Kencana.

Suandi, E. (2017). Perencanaan Pajak. Jakarta: Salemba Empat.

Subekti, W. (2020). Metode Pencatatan Persediaan Untuk Menghitung Harga Pokok Dalam Pengisian SPT Tahunan PPh Badan dan PPh Orang Pribadi Yang Menggunakan Pembukuan Retrieved 11 Maret 2020, 2020

Sugeng, B. (2011). Pengaruh Perencanaan Pajak Terhadap Efisiensi Beban Pajak Penghasilan. Jurnal Riset Akuntansi Dan Bisnis, Volume 11(nomor 2), 122-139.

Sunyatama, Y. D., \& Ngumar, S. (2017). Analisis Beban Penyusutan Aset Tetap dalam Undang-Undang Perpajakan atas Pph Badan. Jurnal Ilmu dan Riset Akuntansi, 6(5).

Syakura, M. A., \& Baridwan, Z. (2014). Determinan Perencanaan Pajak Dan Perilaku Kepatuhan Wajib Pajak Badan. Jurnal Akuntansi Multiparadigma (JAMAL), Volume 5 (2), 185-201.

Tan, W., Sumarsan, T., \& Siahaan, S. (2017). Metode Penyusutan dan Revaluasi Aktiva Tetap Sebagai Bentuk Perencanaan Pajak untuk Meminimalkan Beban Pajak pada PT Waruna, Nusa Sentana. Jurnal Majalah Ilmiah Methoda, 7(3), 24-38. 